\title{
Development and Standardisation of Reaction Scale towards Blended Learning Approach
}

\section{Shireesh Pal Singh ${ }^{1 *}$ and Jubilee Padmanabhan ${ }^{2}$}

${ }^{1}$ Professor, Department of Education, School of Education, Mahatma Gandhi Antarrashtriya Hindi Vishwavidyalaya, Wardha, Maharasahtra, India

${ }^{2}$ Assistant Professor, Department of Education, Central University of Punjab, Bathinda, Punjab, India

*Corresponding author: shireeshsingh1982@gmail.com

Received: 20 Sept., 2020

Revised: 27 Nov., 2020

Accepted: 15 Dec., 2020

\begin{abstract}
Blended learning is a pedagogical approach of incorporating the advantages of both online learning and face- to face learning. In the modern times, when technology is advancing with much greater pace, there is a need to make use of these online platform in the best possible way. But, the use of online mode alone will not serve the purpose of meaningful learning, especially when we look into the nature of different disciplines being very different. It is in this context, that we can make use of a combination of online and face- to face learning in our teaching- learning process. With the invent of various online tools and software, there is a wide scope for incorporating online learning along with face- to face learning. The present paper is based on the development of a Reaction scale for pre- service teachers towards their usage of blended learning strategy in their internship programme (teaching practice). The paper presents an elaborate description on the steps followed for developing a Reaction scale towards blended learning along with the various dimensions taken for developing the Reaction scale and also the validity and reliability process followed for standardization of the scale.
\end{abstract}

Keywords: Reaction, Blended Learning, Standardization

Blended learning, also known as hybrid learning is a new advancement in the technology mediated learning which helps the learners to utilize the advantages of both online and offline (traditional) mode of learning. Hybrid learning is a pedagogical approach that combines face-to- face (F2F) instruction with computer mediated instruction (Ferdig, Cavanaug \& Freidhoff, 2012). The online mode and the offline mode of learning has its own advantages and limitations. These advantages can be maximized and limitations can be minimised by combining the online and face- to face learning. In the present world, where there is availability of more learning resources in the online platform, one can make use of its advantage in the online mode and also the live teacher- student and pupil- pupil interaction can be encouraged in face to face mode of learning. The most significant part of blended learning is that the online component can be accessed by the users at different times according to one's own time and pace. It is such a platform that it can be made use at all time, and can reach number of learners at a time which is independent of time

How to cite this article: Singh, S.P. and Padmanabhan, J. (2020). Development and Standardisation of Reaction Scale towards Blended Learning Approach. International Journal of Inclusive Development, 6(02): 115-121.

Source of Support: None; Conflict of Interest: None 
and place (Dziuban, Hartman \& Moskal, 2004), (Osguthorpe \& Graham, 2003) especially for adult learners. Brown (2003) states that blended learning supports all the benefits of e- learning including cost- reduction, time efficiency and convenience of location. Chung \& Davis (1995) is of view that blended learning provide learners to control their learning pace, select resources according to the interest of learners and time management. The blended mode of learning can happen in either synchronous or asynchronous mode. Though there is difference in the synchronous (online real- time teaching) and asynchronous (without real- time teaching) mode of teaching, in the hands of an experienced teacher both modes can be helpful in improving learning by encouraging interaction among participants, collaborative learning and forming electronic communities of learners (Sotillo, 2000).

The main disadvantage of online learning is that it causes communication hindrance between teachers and learners as well as among the peer groups. This limitation can be solved by combining online and F2F learning. There are different types of learners having varied learning styles and also varied learning needs. Blended learning was effective for learners with diverse learning styles (Bielawski \& Metcalf (2003). Though, blended learning is able to meet the learning needs of diverse learners, the students' views on blended learning such as ease of use of web environment, evaluation, face- to- face environment etc. differ according to their learning styles (Buket et al. (2008). Lim \& Morris (2009) opined that individual learning differences are an important area to consider in making instructional decisions for learner- oriented blended instruction and applicability of learning content is another critical factor of instructional design that help students in sustaining learning interest and promote learning during blended instruction. Boelens, Voet \& De Wever (2018) conducted a study on 20 instructors working in two adult education centres to know what the instructor's strategies and beliefs about differentiated instruction in blended learning. There were three common differentiated instructional strategies i.e. disregard, adaptation and transformation. Disregard means that no additional support is required in blended learning, adaptation means that an increased support in the blended learning arrangements is needed and transformation means that arrangement should be totally redesigned in a different way. The findings show that $50 \%$ of the instructors considered 'transformation' of blended learning arrangements in response to meet the student diversity.

Buket et al. (2008) studied the students' views on blended learning environment in which the students were classified into assimilators and divergers based on their learning styles. Analysis of participation in the online forum in blended learning strategy showed that assimilators were the most active learners while divergers were less active. The results shows that face to face interaction is a must for students and the students' reflective reports and their feedback showed that blended learning was felt to have enhanced their learning opportunities. Student feedback revealed that the provision of the blended learning was highly appreciated and positively rated. Divergers tend to show a greater sensitivity to feelings and thus would be expected to have more interactions with peers and the teachers and assimilators prefer lectures for learning with demonstrations where possible, and respect the knowledge of experts. There were no significant differences between students' achievement scores in respect to their learning styles when taught through blended learning.

As the different students with different learning styles get a varied experience while using the blended learning strategy, it is very important to know about their reaction towards blended learning. The students' response of a Reaction scale can be used for studying the reaction of students towards blended learning which will help the teachers and researchers to know about how well the students could be benefitted from the blended mode of learning. There can be students who enjoyed the blended learning and also there can be students who does not like the blended mode of learning. In order to study this, a Reaction scale was prepared to know the reaction of pre- service teachers who underwent their internship (teaching practice) using the blended mode of teaching. The pre service teachers were trained on the modalities to be followed in blended learning and they were given hands on training on how to adopt blended learning at secondary level. After the completion of their internship, a study was undertaken to know 
their reaction about using the blended learning strategy. In order to serve this purpose a Reaction scale towards blended learning was developed and standardized. The following section deals with the development and standardization process followed in the construction of the Reaction scale towards blended learning.

\section{METHODOLOGY}

To assess the reaction of pupil teachers who has completed their school internship using Blended Learning Approach, a Reaction Scale was developed and standardised. Firstly, the investigator explored the research area and related reviews and found that there are eight dimensions of Blended Learning generally stated in available literature. The initial draft of Reaction Scale towards Blended Learning Approach was developed and applied on 199 respondents for standardisation and establishing reliability and validity of the scale. The table 1 shows the primary draft of Reaction Scale towards Blended Learning Approach. From the various studies, the dimensions for reaction scale towards blended learning was identified as Flexibility in Learning, Online Learning, Learning Management and Classroom Learning, Learning Resources, Online Interaction, Teaching-Learning Environment, Co-Curricular Activities, Evaluation.

Table 1: Primary draft of Reaction Scale towards Blended Learning approach

\begin{tabular}{lll}
\hline $\begin{array}{l}\text { S1. } \\
\text { No. }\end{array}$ & Dimension & $\begin{array}{l}\text { Position of Items } \\
\text { in Scale }\end{array}$ \\
\hline 1 & Flexibility in Learning & $1-4$ \\
2 & Online Learning & $5-9$ \\
3 & Learning Management and & $10-14$ \\
& Classroom Learning & \\
4 & Learning Resources & $15-17$ \\
5 & Online Interaction & $18-21$ \\
6 & Teaching-Learning & $22-25$ \\
7 & Environment & \\
8 & Co-Curricular Activities & $26-30$ \\
\hline
\end{tabular}

Prior to the extraction of the constructs, there are some tests which must be conducted to examine the adequacy of the sample and the suitability of data for factor analysis (Laura J. Burton and Stephanie M. Mazerolle 2011). Sampling adequacy provides the researcher with information regarding the grouping of survey items. Grouping items into a set of interpretable factors can better explain the constructs under investigation.

\section{Examine the Adequacy of the Sample and The Suitability of Data: Kaiser-Meyer-Olkin (KMO) and Bartlett's Test}

Measures of sampling adequacy evaluate how strongly an item is correlated with other items in the exploratory factor analysis correlation matrix (Laura J. Burton and Stephanie M. Mazerolle 2011). The sampling adequacy can be assessed by examining the Kaiser-Meyer-Olkin (KMO) (Kaiser 1970). KMO is suggested when the cases to variable ratio are less than 1:5. It ranges from 0 to 1 , while according to Hair, Anderson et al. (1995); Tabachnick and Fidell, 2001, 0.50 is considered suitable for FA. On the other hand, Netemeyer, Bearden et al. (2003) stated that a KMO correlation above $0.60-0.70$ is considered adequate for analysing the EFA output. Bartlett's test of Sphericity (Bartlett 1950) provides a chi-square output that must be significant. It indicates the matrix is not an identity matrix and accordingly it should be significant $(\mathrm{p}<0.05)$ for factor analysis to be suitable (Hair, Anderson et al. 1995; Tabachnick and Fidell 2001). Bartlett's test of sphericity indicates the item correlation matrix is not an identity matrix, then researchers can move forward with the FA (Netemeyer, Bearden et al. 2003). The analysis of $\mathrm{KMO}$ test is given in table 2.

Table 2: KMO and Bartlett's Test

\begin{tabular}{lll}
\hline \multicolumn{2}{l}{ KMO and Bartlett's Test } \\
\hline \multicolumn{2}{l}{ Kaiser-Meyer-Olkin Measure of Sampling } & 0.858 \\
\hline Adequacy & \\
\hline Bartlett's Test of & Approx. Chi-Square & 3180.953 \\
\cline { 2 - 3 } Sphericity & $\mathrm{df}$ & 595 \\
& Sig. & 0.000 \\
\hline
\end{tabular}

From the table 2 it is it is evident that the Statistic value of Kaiser-Meyer-Olkin test is 0.858 . This value is greater than 0.60 , so the sample is considered adequate for analysing the factor analysis output. The Statistic value of Bartlett's Test is 3180.953, whose probability of significance with df (595) is 0.000 , which is lesser than 0.05 hence, it is significant at 0.05 level of significance. The statistic value is significance $(\mathrm{p}<0.05)$, so the sample is considered adequate for analysing the factor analysis output. 


\section{Item Analysis}

For assessing the item analysis, bi-serial correlation was used to sharpen the scale. The responses were collected and scored. Individual item score was correlated with the total score of the tool. Item analysis was done for the 199 response sheets by using Item vs Whole correlation method. The sum of the scores on each dimension of value was calculated. Then ' $r$ ' was calculated by correlating the individual item and the corresponding component score. The correlation coefficient at the 5\% level of significance is 0.196 when the degree of freedom is 100 (Best, J.W. 2006 and Wani \& Masih, 2016). So the items having ' $r$ ' values 0.196 and above were selected. It was found that all 35 items have significant correlations with the total score of the scale. The correlation coefficient is given in table 3 .

Table 3: r-values of each item with the total score of the scale and decision about selection of item

\begin{tabular}{llllll}
\hline Item & $\begin{array}{l}\text { Corrected } \\
\text { No. }\end{array}$ & $\begin{array}{l}\text { Item-Total } \\
\text { Correlation }\end{array}$ & $\begin{array}{l}\text { Item } \\
\text { Decision }\end{array}$ & $\begin{array}{l}\text { No. } \\
\text { Corrected } \\
\text { Item-Total } \\
\text { Correlation }\end{array}$ & $\begin{array}{l}\text { Item } \\
\text { Decision }\end{array}$ \\
\hline 1 & $0.437^{*}$ & Selected & 19 & $0.519^{*}$ & Selected \\
2 & $0.342^{*}$ & Selected & 20 & $0.522^{*}$ & Selected \\
3 & $0.323^{*}$ & Selected & 21 & $0.555^{*}$ & Selected \\
4 & $0.491^{*}$ & Selected & 22 & $0.617^{*}$ & Selected \\
5 & $0.564^{*}$ & Selected & 23 & $0.529^{*}$ & Selected \\
6 & $0.452^{*}$ & Selected & 24 & $0.621^{*}$ & Selected \\
7 & $0.528^{*}$ & Selected & 25 & $0.568^{*}$ & Selected \\
8 & $0.298^{*}$ & Selected & 26 & $0.260^{*}$ & Selected \\
9 & $0.339^{*}$ & Selected & 27 & $0.488^{*}$ & Selected \\
10 & $0.352^{*}$ & Selected & 28 & $0.508^{*}$ & Selected \\
11 & $0.433^{*}$ & Selected & 29 & $0.560^{*}$ & Selected \\
12 & $0.327^{*}$ & Selected & 30 & $0.486^{*}$ & Selected \\
13 & $0.545^{*}$ & Selected & 31 & $0.552^{*}$ & Selected \\
14 & $0.604^{*}$ & Selected & 32 & $0.277^{*}$ & Selected \\
15 & $0.531^{*}$ & Selected & 33 & $0.512^{*}$ & Selected \\
16 & $0.490^{*}$ & Selected & 34 & $0.249^{*}$ & Selected \\
17 & $0.421^{*}$ & Selected & 35 & $0.543^{*}$ & Selected \\
18 & $0.571^{*}$ & Selected & & & \\
\hline & & & & & \\
\hline
\end{tabular}

${ }^{*}$ Correlation is Significant at 0.01 .

After item analysis correlation of each item with their dimension, bi-serial correlation was used. Individual item score was correlated with the total score of each dimension. A rule-of-thumb is that these values should be at least 0.40 (Joseph A.
Gliem\& Rosemary R. Gliem, 2003). If the correlation between item and the summated score is 0.40 or greater than 0.40 , the item was selected for scale and if the correlation between item and the summated score is lesser than 0.40 , the item was deleted from the scale. Then ' $r$ ' was calculated by correlating the individual item and the corresponding dimension score. It was found that out of the total 35 items, there are 34 items which are having significant correlations with the total score of their respective dimension except one item (Item Number 11) which was having no significant correlation with the total score of their respective dimension. After improvement of the language of this question it was also included in the final draft of scale. The correlation table is given in table 4 .

Table 4: $r$ - value of each item with their dimension and decision about selection of item

\begin{tabular}{llll}
\hline Dimension & Item & Correlation & Decision \\
& No. & & \\
\hline Flexibility in & 2 & 0.604 & Selected \\
Learning & 3 & 0.583 & Selected \\
& 4 & 0.656 & Selected \\
\hline Online & 5 & 0.509 & Selected \\
Learning & 7 & 0.584 & Selected \\
& 8 & 0.662 & Selected \\
& 9 & 0.654 & Selected \\
\hline Learning & 11 & 0.397 & Selected \\
Management & 12 & 0.649 & Selected \\
and & 13 & 0.704 & Selected \\
Classroom & 13 & 0.629 & Selected \\
\hline Learning & 14 & 0.711 & Selected \\
\hline Learning & 15 & 0.716 & Selected \\
Resources & 16 & 0.751 & Selected \\
\hline Online & 18 & 0.559 & Selected \\
Interaction & 19 & 0.527 & Selected \\
& 20 & 0.721 & Selected \\
& 21 & 0.750 & Selected \\
\hline & 22 & 0.573 & Selected \\
& 23 & 0.709 & Selected \\
& 17 & 0.647 & Selected \\
\hline Environment & 0.668 & Selected \\
\hline
\end{tabular}


Development and Standardisation of Reaction Scale towards Blended Learning Approach $\mathcal{P}$

\begin{tabular}{llll}
\hline Co- & 26 & 0.533 & Selected \\
Curricular & 27 & 0.549 & Selected \\
Activities & 28 & 0.559 & Selected \\
& 29 & 0.681 & Selected \\
& 30 & 0.659 & Selected \\
\hline Evaluation & 31 & 0.650 & Selected \\
& 32 & 0.519 & Selected \\
& 33 & 0.605 & Selected \\
& 34 & 0.457 & Selected \\
& 35 & 0.602 & Selected \\
\hline
\end{tabular}

After assessing items correction with scale and with dimensions it was found that all 35 items are having correlation value similar or greater than 0.40, the following table 5 shows the dimension wise distribution of the final draft of Reaction Scale towards Blended Learning Approach.

Table 5: Final Draft of Reaction Scale towards Blended Learning Approach

\begin{tabular}{lll}
$\begin{array}{l}\text { Sl. } \\
\text { No. }\end{array}$ & Dimension & $\begin{array}{l}\text { Position of Items } \\
\text { in Scale }\end{array}$ \\
\hline 1 & Flexibility in Learning & $1-4$ \\
2 & Online Learning & $5-9$ \\
3 & Learning Management and & $10-14$ \\
& Classroom Learning & \\
4 & Learning Resources & $15-17$ \\
5 & Online Interaction & $18-21$ \\
6 & Teaching-Learning & $22-25$ \\
& Environment & \\
7 & Co-Curricular Activities & $26-30$ \\
8 & Evaluation & $31-35$ \\
\hline
\end{tabular}

Face Validity and Content Validity

The content validity of the Reaction Scale towards Blended Learning Approach was tested by 20 experts. It is evident from the assessment of experts that items of the test are directly related to the different dimensions of blended learning.

\section{Construct validity}

In order to find out the construct validity, the researcher calculated correlation between each sub-scale's score and total score of the scale. The correlation coefficient is presented in table 6 .

From table 6, it can be concluded that the correlation coefficient of all dimensions (0.674, 0.727, 0.741, $0.689,0.832,0.839,0.766$ and 0.775 respectively) are significant at 0.01 level of significance. This indicates

that all dimensions of the scale have construct validity.

Table 6: Correlation between Each Dimension and Total Score

\begin{tabular}{lll}
\hline $\begin{array}{l}\text { S1. } \\
\text { No. }\end{array}$ & Dimension & r value \\
\hline 1 & Flexibility in Learning & $0.674^{*}$ \\
2 & Online Learning & $0.727^{*}$ \\
3 & Learning Management and & $0.741^{*}$ \\
& Classroom Learning & \\
4 & Learning Resources & $0.689^{*}$ \\
5 & Online Interaction & $0.832^{*}$ \\
6 & Teaching-Learning Environment & $0.839^{*}$ \\
7 & Co-Curricular Activities & $0.766^{*}$ \\
8 & Evaluation & $0.775^{*}$ \\
\hline
\end{tabular}

*Significance at 0.01 level.

\section{Reliability of the Reaction Scale towards Blended Learning Approach}

The degree of consistency among test scores is called reliability. The values of reliability coefficients (Cronbach alpha) for each sub-scale and for the whole scale are given in table 7.

Table 7: Reliability Coefficient of Reaction Scale towards Blended Learning Approach

\begin{tabular}{lll}
\hline $\begin{array}{l}\text { S1. } \\
\text { No. }\end{array}$ & Description & $\begin{array}{l}\text { Cronbach's } \\
\text { Alpha }\end{array}$ \\
\hline 1 & Flexibility in Learning & 0.393 \\
2 & Online Learning & 0.554 \\
3 & Learning Management and & 0.598 \\
& Classroom Learning & \\
4 & Learning Resources & 0.510 \\
5 & Online Interaction & 0.526 \\
6 & Teaching-Learning & 0.626 \\
7 & Environment & 0.559 \\
8 & Co-Curricular Activities & 0.490 \\
9 & Evaluation & 0.897 \\
\hline
\end{tabular}

From table 7 it is evident that all the sub scales and full scale is having a good reliability index. Hence, the final Reaction Scale towards using Blended Learning Approach for Teachers Preparation included 35 statements, covering a total of eight dimensions determined based on the nature of the blended learning teaching-learning environment. 
Table 8: Dimension's wise Distribution of Statements in Reaction Scale

\begin{tabular}{|c|c|c|c|c|c|}
\hline S1. No. & Dimension & $\begin{array}{l}\text { Nature of } \\
\text { Statements }\end{array}$ & $\begin{array}{l}\text { Position of } \\
\text { Statements }\end{array}$ & $\begin{array}{l}\text { Number of } \\
\text { Statements }\end{array}$ & Total no. of items \\
\hline \multirow[t]{2}{*}{1} & Flexibility in Learning & Positive & $1,3,4$ & 3 & 04 \\
\hline & & Negative & 2 & 1 & \\
\hline \multirow[t]{2}{*}{2} & Online Learning & Positive & $6,7,9$ & 3 & 05 \\
\hline & & Negative & 5,8 & 2 & \\
\hline \multirow[t]{2}{*}{3} & Learning Management and & Positive & $10,12,13,14$ & 4 & 05 \\
\hline & Classroom Learning & Negative & 11 & 1 & \\
\hline \multirow[t]{2}{*}{4} & Learning Resources & Positive & 16,17 & 2 & 03 \\
\hline & & Negative & 15 & 1 & \\
\hline \multirow[t]{2}{*}{5} & Online Interaction & Positive & 18,19 & 2 & 04 \\
\hline & & Negative & 20,21 & 2 & \\
\hline \multirow[t]{2}{*}{6} & Teaching-Learning Environment & Positive & 22,24 & 2 & 04 \\
\hline & & Negative & 23,25 & 2 & \\
\hline \multirow[t]{2}{*}{7} & Co-Curricular Activities & Positive & $27,29,30$ & 3 & 05 \\
\hline & & Negative & 26,28 & 2 & \\
\hline \multirow[t]{3}{*}{8} & Evaluation & Positive & $32,33,34$ & 3 & 05 \\
\hline & & Negative & 31,35 & 2 & \\
\hline & TOTAL & & & & 35 \\
\hline
\end{tabular}

Table 9: Student responses and its corresponding scores

\begin{tabular}{lllllll}
\hline S1. No. & $\begin{array}{l}\text { Nature of } \\
\text { statements }\end{array}$ & Strongly Agree & Agree & Undecided & Disagree & Strongly disagree \\
\hline 1 & Positive & 5 & 4 & 3 & 2 & 1 \\
2 & Negative & 1 & 2 & 3 & 4 & 5 \\
\hline
\end{tabular}

The dimension-wise distribution of the reaction scale is presented in table 8 .

\section{Scoring Method}

The scoring of each respondent's sheet was done with the help of the answer key. On the Strongly Agree, Agree, Undecided, Disagree, and Strongly Disagree responses to positive statements of the applicant were awarded 5, 4, 3, 2, and 1 marks respectively and 1,2,3,4, and 5 marks on negative statements respectively. The scoring of positive and negative items are given in table 9 . Thus the range of scores on the scale was 35-175.

\section{CONCLUSION}

With the advent of technology- mediated teachinglearning, there has been more emphasis on online mode of teaching and learning. This can be a threat for the understanding of various disciplines since, the nature of disciplines varies from one another. But, if an attempt is made to incorporate the advantages of both online and face- to- face learning, the problem arising from more emphasis on online learning platform can be minimised and we can assure meaningful learning among students. The present paper was meant to develop and standardise a reaction scale which can be used for students or pre service teachers who has used the blended mode of teaching-learning. The Reaction scale towards using blended learning approach was developed and standardized wherein the validity and reliability was established. The final reaction scale consists of 35 items on a five- point scale having the ratings as "Strongly agree, Agree, Undecided, Disagree and Strongly disagree". The scale was constructed on the basis of eight dimensions i.e., Flexibility in Learning, Online Learning, Learning Management and Classroom Learning, Learning Resources, Online Interaction, Teaching-Learning Environment, Co-Curricular Activities and Evaluation which are decided based on thorough review of various studies. The reaction 
scale can be used by respondents who has been using the blended mode of teaching.

\section{REFERENCES}

Bartlett, M.S. 1950. Tests of significance in factor analysis. British Journal of Psychology, 3(2): 77-85.

Bielawski, L. and Metcalf, D. 2003. Blended e-learning: Integrating knowledge, performance support, and online learning, Amherst, MA: HRD Press.

Boelens, R., Voet, M. and De Wever, B. 2018. The design of blended learning in response to student diversity in higher education: Instructors' views and use of differentiated instruction in blended learning. Computers and Education, 120: $197-212$

Brown, R. 2003. Blending learning: Rich experiences from a rich picture. Training and Development in Australia, 30(3): 14-17.

Buket, A. and Soylu, M.Y. 2008. A Study of Student's Perceptions in a Blended Learning Environment Based on Different Learning Styles. Journal of Educational Technology $\mathcal{E}$ Society, 11(1): 183-193.

Chung, J. and Davis, I.K. 1995. An instructional theory for learner control: Revisited. In M.R. Simonson (Ed.), Proceedings of the 1995 Annual National Convention of the Association for Educational Communications and Technology, Anaheim, CA: AACE, pp. 72-86.

Dziuban, C.D., Hartman, J.L. and Moskal, P.D. 2004. Blended learning, Educause Center for Applied Research, Research Bulletin, 7, retrieved January 15, 2008, from http://www. educause.edu/ir/library/pdf/ERB0407.pdf.

Ferdig, R., Cavanaugh, C. and Freidhoff, J. 2012. Lessons learned from blended programs: Experiences and recommendations from the field. Vienna, VA: iNACOL.

Gliem, J.A. and Gliem, R.R. 2003. Calculating, interpreting, and reporting Cronbach's Alpha Reliability Coefficient for Likert-Type Scales, Midwest Research-to-Practice Conference in Adult, Continuing, and Community Education, The Ohio State University, Columbus, October pp. 8-10.

Hair, J., Anderson, R. et al. 1995. Multivariate data analysis. New Jersey, Prentice-Hall Inc.

House, R.J., Hanges, P.J., Javidan, M., Dorfman, P.W. and Gupta, V. 2004. Culture, leadership, and organizations: The GLOBE study of 62 societies. Journal of Cross-Cultural Psycology, 36(5): 628 - 630.
Joo-seng, T. 2004. Blended Learning and the global economy. Leadership in Action, 24(5): 19-21.

Kaiser, H.F. 1970. A Second-Generation Little Jiffy. Psychometrika, 35(4): 401-415.

Laura J. Burton and Stephanie M. Mazerolle. 2011. Survey Instrument Validity Part I: Principles of Survey Instrument Development and Validation in Athletic Training Education Research. Athletic Training Education Journal, 6(1): 27-35.

Lim, D.H. and Morris, M.L. 2009. Learner and Instructional Factors Influencing Learning Outcomes within a Blended Learning Environment. Educational Technology \& Society, 12(4): 282-293.

Netemeyer, R.G., Bearden, W.O. et al. 2003. Scaling Procedures: Issues and Applications. London, Sage.

O'byrne, W.I. and Pytash, K.E. 2015. Hybrid and Blended Learning: Modifying Pedagogy Across Path, Pace, Time, and Place, Journal of Adolescent \& Adult Literacy, 59(2): 137140.

Osguthorpe, R.T. and Graham, C.R. 2003. Blended learning environments: Definitions and directions. Quarterly Review of Distance Education, 4(3): 227-233.

Sotillo, S.M. 2000. Discourse functions and syntactic complexity in synchronous and asynchronous communication. Language Learning ó Technology, 4(1): 82-1.

Tabachnick, B.G. and Fidell, L.S. 2001. Using multivariate statistics. Needham Heights, MA, Allyn \& Bacon.

Van Dyne, L., Ang, S. and Koh, C. 2008. Development and validation of the CQS: The Readiness Scale towards Blended Learning Approach. In: S. Ang \& L. Van Dyne (Eds.), Handbook of Blended Learning: Theory, measurement, and application (pp. 16 -38). Armonk, NY: M.E. Sharpe, Inc.

Van Dyne, L., Ang, S. and Koh, C.K.S. 2009. Blended Learning: Measurement and scale development. In: M.A. Moodian (Ed.), Contemporary leadership and intercultural competence: Exploring the cross-cultural dynamics within organizations (pp. 233-254). Thousand Oaks, CA: Sage.

Wani, M.A. and Masih, A. 2016. Likert Scale Development: Construction and Evaluation of Home Environment Scale. International Journal of Humanities and Social Sciences, 8(5): 18-26. 
